issued clandestinely, as no name of printer or of the place of printing appears on its title-page, though Mr. Russell Martineau informs me that the type shows it to have been printed in London.

There are two copies in the British Maseum library, the pressmark of the one in the Thomason collection being E. 89. 1. I learn from Mr. Dexter's admirable Bibliography appended to 'The Congregationalism of the last Three Handred Years' that there is a copy in the Bodleian and another in America.

It would be interesting to trace the authorship of such a work. It seems most unlikely that a writer who was capable of this had never written anything else. Many possible names have arisen in my mind, only to be finally rejected.

The only known writer intellectually likely to be the father of it is Selden; but it contains blunders on constitutional law which put Selden out of the question, unless, indeed, he deliberately inserted them, and a certain warmth of tone in speaking of religion, which was foreign to him, in order to conceal his identity.

Bamuel R. Gardiner.

\title{
MATHER AND RANDOLPH
}

(Contribated by C. E. Dobue)

AT the end of vol. xii. of the Ballard MSS. in the Bodleian Library, containing a very interesting series of letters from Dean Hickes (of Worcester, deprived) to Dr. Arthur Charlett, master of University College, 1692-1722, there is a copy in Dr. Charlett's elegant handwriting of a letter of some historical, or at least biographical, interest. It is from Edward Randolph to Dr. Hickes, covering a letter from Increase Mather. Charlett has inadvertently transcribed the signature as 'Increase Master,' and the historical import of the letter appears to have been unnoticed by subsequent readers accordingly. Edward Randolph was the well-known emissary of Charles II and James II, whose intrigue against the liberties of New England was only frustrated by the revolution. All the histories of the Mathers, and indeed of New England, make mention of a letter dated 9 Dec. 1688, which purported to be written by Increase Mather to a friend at Amsterdam (Pond, 'Life of Increase Mather,' pp. 97 sq. ; 'Memoirs of the Life of the late Rev. Increase Mather, D.D.' (1725), p. 35 ; Hutchinson, ' History of Messachusetts' (Salem, 1795), vol. i. p. 827 ; Palfrey, 'History of New England,' vol. iii. pp. 656 sqq.) Mather, on hearing that it had come into Randolph's hands and that Randolph was making use of it to damage him, not only repadiated its authorship, but declared it to be a forgery of Randolph's own. Palfrey suggests-the suggestion reminds one of Horace Walpole's favourite phrase ' to cross over and figure in '-that it was really the production, not of Increase, but of his son Cotton, Mather, and that the former intended to attribute its fabrication, not to Edwoard Randolph, but to his brother Barnard. At all events the letter of Randolph's here published shows him to us as making use of the forged letter several years earlier than that referred to by Palfrey (vol. iii. p. 566). There is a copy of the forged letter in 
the Record Office, and extracts from it were printed by L'Estrange in his 'Observator,' Nos. 179, 174, and 176 (26 and 27 Nov. and 1 Dec. 1684), but I cannot find, after a necessarily imperfect search, that it has yet been printed in extenso. I may add that it seems difficalt to believe that the forgery-if forgery there were-was Edward Randolph's.

[BodL. MSS. BALTARD XI. 150]

To the Reverend Dr. Hicks Deane of Worcester at his house in Worcestor.

Whitehall, Sept. 20"t 84 .

$\mathrm{S}^{r}$, - I should disoblige myselfe, to omitt communicating the Enclosed to you, who have formerly espoused \& taken paines in the Procoedings agt $y^{0}$ Bostoners, who as I told you at my coming away were greatly divided, \& by letters since receaved from thence are almost impatient, till his majesty has accomplished that Settlement, so long \& so hesvily carried on. The Faction there last Election turned out all Persons, ( ${ }^{\circ}$ Governor poor old man excepted) in the Magistracy, who voted for a Submission to his Majestys gracious Proposels: So that now they have $y^{\circ}$ sole Government in theyr hands, yo Writer of $y^{\circ}$ Inclosed being a very hot headed Man, has a great Influence upon the Party: \& what Cnipperdoling \& John of Leyden at Munster perswaded the People to by theyr enthusiastick Dreams \& Visions, this Man does by his Intimacy with the Starrs \& Planets, being a great Prognosticator, as by severall of his books upon Cometts \&c. When I may be so happy to wait upon you in London, I shall make my Remarks with you upon severall Parts of $y^{\circ}$ letter: In generall it makes me beleive, there was a good Understanding betwixt the late Plotters here, \& $y^{*}$ Faction in New England maintained \& carried on by $y^{\circ}$ Medium of $y^{\circ}$ Fanaticks in Holland : it is full of Treason, Cant, \& Lyes.

It is true $y^{\circ}$ next day I arrived at Boston, there was a great Fire in Boston, but no man thought me concerned Further than to be sorry for that Calamity, which fell heavy upon very honest Gentlemen, but this was to represent me to $\mathrm{y}^{\circ}$ World what he has not spared to give out in Boston : He tells a great Lye in saying $\mathrm{y}^{\bullet} \mathrm{King}$ was well pleased in theyr sending away the Com̃issioners \&cc.; you may remember the King in $\mathbf{1 6 6 4}$ was at great Charge in sending over Commissioners thither upon sundry complaints made at $\mathrm{y}^{\circ}$ Councill board \& instead of admitting them to Act according to theyr Commission they openly by sound of Trumpet declared agst theyr Proceeding and would not permitt them to stay as Compissioners in Boston and so returned re infecta, and this high Contempt of theyrs was one Article agst them: Bat how this wicked Party will abuse the World by telling such palpable Untruths: I must not leave of my Old Trade with you, having lived in Scotland to beg your book of Jovian agst Julian: I design to carry that with other good books to New England \&c.

Your obliged Freind and Servant

E. RANDOLPH. 
Boston in New England $y^{34}$ of $y^{+10^{-m}} 1683$.

$\mathrm{S}^{\mathrm{r}}$,-I am obliged for your favor in writing me by our Agents Returne ; which letter I have recesved \& observe $w^{t}$ you write concerning affairs in England, \& how our Freinds are there wrongfully abused. I am glad God has preserved our Good Freind Mr. Ferguson, \& sent him over to your side $y^{\circ}$ Water, where theyr malice cannot reach him: We have before yours came to hand heard yo Great Bufferings of several of $y^{*}$ Servants of $y^{\circ}$ Lord. What you gay as to theyr Intentions to root out Gods word among us, I will say with y $\mathrm{L}^{\mathrm{d}}$ Prophet Devid, The Righteous also shall soe this \& feare \& shall laugh them to Scorn: ${ }^{1}$. . . I am well assured of $y^{\circ}$ heppinesse of that great Freind of Gods causse yo Lord of Shaftsburry, who you say dyd in our good Freind Mr. Kecks house, if they could he should certainly have been cut of by those evil doers, for they can new mould law日 as they please, \& make it theyr Studdy more to please men then God. Corrupt are they, \& become abominable in theyr wickednesse, there is none that doth Good: Jehovah lookd down from heaven to see if there were any would understand \& seek after him, no all are seeking after Vanity \& have not god before theyr eys, yea, from $y^{\circ}$ King that sitteth upon the throne to the beggar. It was a great greif to me to heare $y^{\circ}$ desth of that good Lord Rassell, \& how barbarously $y^{\circ}$ Earl of Essex was murthered in $y^{\circ}$ Tower, we may seo with half an eye which way they intend to drive Poore England. Well ; we can only say with holy David, Oar God shall come and shall not keep silenoe, there shall goe before him a consuming Fire, a Mighty Tempest shall be stirred up round about him to whom we will committ all our Concernes. I thank you for $\mathrm{y}^{\mathrm{r}}$ Care in getting those Prints in readinesse, pray let me have $y^{\bullet}$ following books sent in $y^{\circ}$ same ship with them; The New covenant in Scotland, Caryl on Job, Mr. Owens last works, \& [ ] of your new Geneva Prints, that I may collect of all to sweeten y० milk to the Palate of these good Christians, who praised be God recesve with Cheerefullness our Administration : . . .

I am glad to heare the Lord hath raised ap a Defender for his People in Hungary, \& I am certainly of Opinion the Lords work will be done by those Hesthens, \& the Whore of Babylon shall fall, his late signes in $y^{\circ}$ heavens did foretell as much, my Prayers shall be continually for theyr Victory, for certainly it is his Will it shall be so. . . .

As to affairs in these parts which you desire to have account of, I shall tell you $y^{\bullet}$ same week our Agents arrived, Randulph also arrived, with a Summons from $\mathrm{y}^{\circ} \mathrm{King}$ for our Charter. The next day after he arrived was a asd Fire, burnt down the richeat part of $y^{\circ}$ Town, which some believe was done by his meanes, for some few days after he went out of Town, or certainly he would have ended theyr days throe some of $y^{\circ}$ Tumultuous Bufferers : He has made it his businesse to spread the Kings Declaration all about $y^{*}$ Country, and perswaded two Colonys to fall of from uniting with us: A Genersl Court hath been called here \& held 14 days. The Governor \& several of our Magistrates not regarding God or theyr Country have voted to surrender theyr Charter to $\mathrm{y}^{\bullet} \mathrm{King}: \mathrm{But}$ $y^{\circ}$ Deputy Governor with several other magistrates, and most of $y^{\text {b house }}$

1 This and subsequent marks of elision are reproduced from the original. 
of Deputys who feare God more then man are for Keeping our Priviledges, which is my Opinion also. And whatever the Event may be, we ought to stand by them with our lives \& Fortanes, for so Abab required Naboths Vineyard.

We have had great incouragement from our Freinds in England, for several Good \& worthy men among y Law Doctors, have connselled us to stand it out at low. Bat in Englend Mony will do much. This Randulph has been a mortal Enemy to our Country \& most say if he had not often moved his Majesty, he would not have been concerned, for he was satisfyed with our sending away $y^{\circ}$ Comissioners. It has cost these people much mony, \& if 2 or 8000 will bay it of, we have those who will give it. We have good Freinds in England who will largely contribute, but dare not be seen for feare of Trouble. We expect great Quantitys of Freinds to come over from England. God will certainly avenge the blood of his Saints, \& those that live shall feare our great Jehovah. . . . Pray when you see Mr. Fergason, give him my kind Balutes, if he continue his resolutions of coming over hither, he shall find a most hearty welcome, but I feare he must be forced to change his neme, for tho we have power in our Charter to protect such as fly from Persecution as wee did Goffe \& Whaly, yet we feare that Priviledge will be forced from us: God grant we may keep our heavenly Charter, purchesed by Jesus, that also would be demanded if some durst. But now a Jesuite is a Courtier \& what you will so he is no enemy of $\mathrm{y}^{\circ}$ Court, he may be any thing.

Some report that Mr. Oates is out of Favor for discovering yo Popish Plot, \&as; hed he but eworn for them, he would certainly have been a Bishop, if $\mathrm{B}^{\mathbf{r}} \mathrm{L}$. J[enkins] pleased : This comes to you by $\mathrm{y}^{\circ}$ way of Barbsdos by a Jew. My Service to Mr. Keck, his Son is hopefull \& one that feares yo Lord. Randulph is retarned, God will certainly follow him, for he has done us much prejudice; if he miscarrys in his Voyage, its Gods just judgement. I will conclude the $L^{d}$ liveth, Jehovah is his name. Yn in Jesus Christ

I. M.

Increase Master Minister of $y^{*} z^{4}$ Independent Charch in Boston.

To my Worthy Freind Mr. Gouge Minister in Amsterdam.

[Endorsed by Bellard] Mr. Randolph Life. to Dean Hicks from Boston in New England. Mr. Masters a canting Minister Life. from thence to Mr. Gonge.

\section{THE CaMPaign OF GENERAL BRADDOCK}

(Commanicated by J. Coor WrisoN)

The writer of the following letter was one William Jolnston. a commissariat officer attached to the force of General Braddock, whose operations egainst Fort $\mathrm{Du}$ Quesne terminated so disastrously to the British arms. Fortunately for himself, he (together with the military chest of which he was in charge) was in the second of the corps into which the general divided his little army, and so escaped the fate which overtook so large a proportion of the men and officers composing the advanced force.

The letter itself needs little comment. The unhappy story has been 